\title{
Evaluation of parameters related to libido and semen quality in Zebu bulls naturally infected with Trypanosoma vivax
}

Joely FF Bittar', Paula B. Bassi', Dênia M. Moura', Guilherme C. Garcia', Olindo Assis Martins-Filho², André B. Vasconcelos ${ }^{1}$, Matheus F. Costa-Silva ${ }^{1,2}$, Cristiano P. Barbosa', Márcio SS Araújo 1,2* and Eustáquio R. Bittar ${ }^{1}$

\begin{abstract}
Background: Trypanosomiasis is a disease caused by Trypanosoma (Dutonella) vivax, a hemoprotozoa that can affect bovines. In South America, the sanguineous form is mechanically transmitted from one mammalian host (ruminant) to another by the bite of a blood-sucking insect or by needles contaminated with infected blood. The negative impact of the parasitosis caused by T. vivax infection on the reproductive activity of male and female ruminants is known to reduce fertility. In males, alterations such as degeneration, diffuse or interlobular inflammatory infiltrate found in ovine and bovine testicles, can affect fertility through decreased sperm quality. This study evaluated the impact of natural infection with T. vivax on Zebu bulls from the Central Station of Artificial Insemination (CSAI) with regard to libido and the negative effects caused by this protozoan on semen quality.

Methods: Blood samples of 44 animals were collected to evaluate the presence of the trypomastigote form of T. vivax in blood smears obtained from hematocrit and buffy coat, and antibody titer lgG anti T. vivax in indirect. Immunoflorescence (IFI). Furthermore, data related to libido, ejaculate volume, spermatic concentration, and seminal vigor were recorded for these animals employing the criteria of the CSAI.

Results: Nine animals (20.45 \%) showed T. vivax trypomastigotes and parasitemia between 0.02 and 0.07 , and antibody titers from 1:80 to 1:320 in IFI. Twenty nine negative animals in parasitological tests were not reactive in IFI, and six animals presented the antibodies IgG anti T. vivax in IFI. Data on reproductive activity showed that animals infected with T. vivax have a decreased libido and an increased spermatic volume, whereas other factors related to the reproductive process such as spermatic concentration, motility and spermatic force, were unchanged in infected bulls.

Conclusions: The T. vivax infection in Zebu bulls from CSAI caused patent parasitemia, induced a febrile state, promoted reduction in the libido and increased the ejaculate volume. These conditions together may account to decrease the performance of these animals.
\end{abstract}

Keywords: Trypanosoma vivax, Libido, Reproduction, Bull, Semen

\footnotetext{
* Correspondence: sobreira@cpqrr.fiocruz.br

'Universidade de Uberaba (UNIUBE), Programa de Mestrado acadêmico em Sanidade e Produçao Animal nos Trópicos, Avenida Nenê Sabino 1697/1698, 38055-500, Uberaba, MG, Brasil

${ }^{2}$ Laboratório de Biomarcadores de Diagnóstico e Monitoração, Centro de Pesquisas René Rachou - Fundação Oswaldo Cruz, Avenida Augusto de Lima n 1715, 30190-002 Barro Preto, Belo Horizonte, MG, Brasil
}

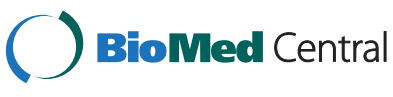

(c) 2015 Bittar et al. Open Access This article is distributed under the terms of the Creative Commons Attribution 4.0 International License (http://creativecommons.org/licenses/by/4.0/), which permits unrestricted use, distribution, and reproduction in any medium, provided you give appropriate credit to the original author(s) and the source, provide a link to the Creative Commons license, and indicate if changes were made. The Creative Commons Public Domain Dedication waiver (http://creativecommons.org/publicdomain/zero/1.0/) applies to the data made available in this article, unless otherwise stated. 


\section{Background}

Trypanosomiasis is a disease caused by Trypanosoma (Dutonella) vivax, a hemoprotozoan that can affect bovines [1]. In South America, the sanguineous form is mechanically transmitted from one mammalian (ruminant) host to another by the bite of a blood-sucking insect or by fomites, mainly needles contaminated with infected blood. After skin penetration, the protozoon reaches the bloodstream via the lymphatic system and undergoes a prepatent period of 10 to 14 days [2]. T. vivax occurs in the majority of tropical countries and represents a potential problem to bovine herds. In Brazil, ruminants naturally infected with $T$. vivax can experience a chronic and asymptomatic infection that is difficult to diagnosis throughout herds. This phenomenon, called trypanotolerance, has a genetic and an environmental component and can vary with age, nutritional status, stress conditions, intercurrent infections, and the strain involved [3, 4]. The disease was introduced in America probably during the 19 th century by European colonizers. Studies conducted in Brazil revealed that this hemoparasite has been found in animals in the states of Tocantins [5], Paraíba [6], Maranhão [7], Minas Gerais [8], and mainly in the region of the Pantanal in Mato Grosso [9].

The negative impact of $T$. vivax on the reproductive activity of male and female ruminants has been shown to result in a reduction in fertility with a significant impact on herd productivity [2, 10]. The clinical signs of trypanosomiasis include anemia, fever, lethargy, progressive weight loss, decrease in fertility, reduced production of milk and meat, abortions, agalaxia, and eventually death $[11,12]$.

Trypanosomiasis is responsible for many reproductive disorders in bovine herds such as the degeneration of the hypothalamus, the pituitary gland, and the gonads causing, as a consequence, alterations to the concentration of secretions and plasmatic concentrations of essential hormones for reproduction in both males and females $[2,10]$. In males, alterations such as degeneration, diffuse or interlobular inflammatory infiltrate found in ovine and bovine testicles, can directly affect the fertility of the animals through decreased sperm quality. The affected parameters are volume, concentration, viability, motility and spermatic pathology, showing that not only females infected with $T$. vivax have reproductive issues $[13,14]$.

As there is little information regarding the effect of T. vivax on the libido or semen volume and quality of Zebu bulls in Brazil, this study aimed to diagnose the presence of Trypanosoma vivax infection from donator bulls from the Central Station of Artificial Insemination (CSAI) and verify the negative effects caused by this protozoan on libido and semen features in naturally infected bulls.

\section{Methods}

Animals

This work was conducted at the Veterinary Hospital of Uberaba and in a laboratory associated with the Central Station of Artificial Insemination (CSAI) in Uberaba, Minas Gerais, Brazil. Forty-four Zebu bulls (Bos indicus) in reproductive age varying from 3 to 14 years from the CSAI were evaluated. The presence of the trypomastigote form of T. vivax had already been detected at CSAI from blood smears of peripheral blood of a cow used in a practical artificial insemination class. The bulls received a daily diet of $30 \mathrm{k}$ of ground forage grass (Napier grass) and $4 \mathrm{k}$ of maintenance feed in addition to Estrela grass, which was the natural paddock hay, and water ad libitum. At the time of blood collection, rectal temperature was measured and a clinical examination of the animals was performed (behavior, palatability and mucosa color). This study protocol was approved by the Animal Experimentation Ethical Committee from Universidade de Uberaba, Uberaba, Minas Gerais, Brazil (CEEA/UNIUBE, protocol number 001/2013) and followed all the ethical principles of cattle experimentation procedures.

\section{Blood sampling and assessment of parasitemia}

For the identification of the blood trypomastigote form of $T$. vivax, blood samples were collected by jugular venipuncture into sterile vacuum tubes containing an anticoagulant (EDTA $7.2 \mathrm{mg}$ ). Blood was also collected into sterile vacuum tubes without anticoagulant for further investigation of the antibodies IgG anti-T. vivax using the technique of indirect immunofluorescence, adapted from the classical method proposed by Camargo et al. [15].

To identify $T$. vivax-positive animals, observations were performed using the methodology described by Woo [16]. For each animal, two micro-hematocrit tubes were filled to $2 / 3$ of their volume and had the rear end sealed by flame. The tubes were then centrifuged at $15,000 \mathrm{~g}$ to obtain the buffy coat suspension. Blood smears were made by breaking the micro-hematocrit tubes in the area of transition between plasma and leukocyte and placing the part containing the erythrocytes on the slide for the smear confection. The blood smear was dyed with quick panoptic $\left(\right.$ Hematocor-Biocor $\left.^{\oplus}\right)$. Slides were subsequently observed using an optical microscope with a 100x immersion oil objective. The calculation of parasitemia of positive animals was performed following the method described by Brener [17], which involved determining the number of T. vivax observed in ten fields of view, multiplying this number by 100 and dividing it by the number of red blood cells in all ten fields $(+/-1000)$.

Trypomastigotes observed in blood smears were measured using the morphometric program (Image Tool $^{\circledR}$ ). Measurements and observations recorded were: total 
length of parasite including free flagellum (L), distance from the end of posterior extremity to kinetoplast (PK), distance from kinetoplast to the middle of the nucleus $(\mathrm{KN})$, distance from the end of posterior extremity to the middle of the nucleus (PN), distance from the middle of the nucleus to the end of anterior extremity (NA), length of free flagellum (F), kinetoplast index (KI), and nuclear index (NI). Measurements were made following the method described by Hoare [18] and the trypomastigotes were compared with those described from Brazil by Carvalho [8], Linhares [5], Shaw \& Lainson [19], Silva et al. [9] and Paiva et al. [20], in the Table 1.

\section{Serological test (indirect immunofluorescence - IFI)}

To perform indirect immunofluorescence, slides containing trypomastigotes of $T$. vivax were used. The slides were produced using ovine blood that was experimentally infected. The experimental infection followed the ethical principles of animal experimentation adopted by Ethics in Animal Experimentation Committee (CEEA/UNIUBE, protocol number 035/2012). At the highest parasitemia $\left(2 \times 10^{7}\right.$ trypanosomes $/ \mathrm{mL}$ of blood $) 100 \mathrm{~mL}$ of blood was collected in vacuum tubes containing EDTA. Parasites were obtained following the protocol described by Cuglovici et al. [21], with modifications. The blood was mixed with Percoll Solution $\left(\mathrm{Sigma}^{\circ}\right)$ in same proportion and centrifuged at $17,500 \mathrm{~g}$ for $20 \mathrm{~min}$ at $4{ }^{\circ} \mathrm{C}$. The parasite layer formed near the top of the gradient and was collected and re-suspended in phosphate buffered saline (PBS of NaH2PO4 $40 \mathrm{mM}, \mathrm{pH} 7.5$ and $\mathrm{NaCl}$ $150 \mathrm{mM}$ ) in the proportion of 1:3. The suspension was then centrifuged at $6000 \mathrm{~g}$ for $15 \mathrm{~min}$ at $4{ }^{\circ} \mathrm{C}$, the supernatant discarded, and the sediment washed twice with PBS $6000 \mathrm{~g}$ for $15 \mathrm{~min}$ at $4{ }^{\circ} \mathrm{C}$ aiming to remove any remaining of Percoll. The partially purified trypanosomes were distributed on pre-demarcated glass slides. After natural drying, the slides were fixed in cold acetone for $5 \mathrm{~min}$ and again naturally dried, wrapped in paper tissues and aluminum foil, and stored at $-20{ }^{\circ} \mathrm{C}$ until the moment of use.
The serums obtained from animals to be tested were diluted in the ratio 1:2 to1:640 in PBS. The detection of the antibodies IgG anti-T. vivax was done employing a rabbit antibody anti-bovine IgG conjugated with fluorescein isothiocyanate (Sigma St Louis, MO, USA) in dilution of 1:200 in PBS. Serum samples that were reactive in dilution 1:80 or greater were considered positive [20].

\section{Hematological analysis}

The analysis of Red Blood Cell (RBC) included erythrocyte counts, hemoglobin concentration, hematocrit, Mean Corpuscular Volume (MCV), Mean Corpuscular Hemoglobin Concentration (MCHC). The White Blood Cell (WBC) included total and differential leukocyte counts. All hematological measurements were carried out in a hematology analyzer (ABC VET - Horiba ${ }^{\circ} \mathrm{ABX}$ Diagnostics). The differential leukocyte count was performed by optical microscopy (Nikon Eclipse E200 ${ }^{\circ}$ ), 1000× magnification, of blood smears stained with Fast Panoptic kit (Laborclin ${ }^{\circ}$ São José do Rio Preto - SP).

\section{Evaluation of features related to reproductive activity}

The data concerning libido, ejaculate volume, seminal concentration, and spermatic vigor were obtained following the CSAI criteria. For evaluation of libido, the methodology described by Fonseca \& Chow [22], was followed with some modifications. Five cows were brought to estrus after application of prostaglandin $\left(\mathrm{PGF}_{2} \alpha\right)$. The bulls were individually tested for a 3-h time frame and their performance was documented every $5 \mathrm{~min}$. Libido was classified using the table of libido classification for Zebu bulls of the Brazilian College of Animal Reproduction [23]: 0 to $3=$ questionable; 4 to $6=$ good; 7 to $8=$ very good; 9 to $10=$ excellent or superior.

The semen was analyzed for volume, concentration, motility and spermatic vigor the standards set by the Ministry of Agriculture and the Brazilian College of Animal Reproduction [23]. Sperm collection employed an artificial vagina and the evaluation was done individually.

Table 1 Comparison of biometric averages of Trypanosoma vivax from Zebu bulls from the Central Station of Artificial Insemination (CSAI) and other isolates in Brazil ${ }^{a}$

\begin{tabular}{|c|c|c|c|c|c|c|c|c|}
\hline Locality & $\mathrm{L}$ & PK & $\mathrm{KN}$ & PN & NA & $\mathrm{F}$ & $\mathrm{Kl}$ & $\mathrm{NI}$ \\
\hline Minas Gerais (CSAI) - Present study & 20.56 & 0.86 & 5.44 & 6.31 & 5.62 & 6.44 & 1.16 & 1.54 \\
\hline Minas Gerais [8] & 19.89 & 0.90 & 6.64 & 7.55 & 7.46 & 6.22 & 1.04 & 1.14 \\
\hline Tocantins [5] & 19.42 & 0.96 & 6.24 & 7.25 & 5.87 & 6.29 & 1.16 & 1.24 \\
\hline Pará [18] & 22.77 & 0.65 & 6.16 & 7.60 & 8.22 & 6.92 & 1.23 & 0.94 \\
\hline Mato Grosso [9] & 18.73 & 1.02 & 6.10 & 7.18 & 5.40 & 6.15 & 1.17 & 1.50 \\
\hline Mato Grosso do Sul [19] & 18.10 & 0.30 & 7.46 & 7.76 & 6.03 & 4.30 & 1.04 & 1.34 \\
\hline
\end{tabular}

${ }^{\mathrm{a}}$ Data are presented in $\mu \mathrm{m} . L$ total length of parasite, including free flagellum, $P K$ distance from the end of posterior to kinetoplast, $K N$ distance from kinetoplast to the middle of the nucleus. $P N$ distance from the end of posterior extremity to the middle of the nucleus, NA distance from the middle of the nucleus to the end of anterior extremity. $F$ free flagellum length, $K I$ kinetoplast index, $N I$ nuclear index 


\section{Statistical analysis}

Data were reported as means and standard deviations and analyzed using the student $t$ test with graph pad prism $^{\circledR}$ version 5.0 software (GraphPad Software, San Diego, CA, USA). Data were considered statistically different with $P<0.05$.

\section{Results}

Evaluation of the blood smears allowed the identification of the trypomastigote form of T. vivax (Fig. 1a) in 9 of 44 animals $(20.5 \%)$ with parasitemia ranging from 0.02 to $0.07 \%$. The biometric data of the trypomastigotes found in positive samples were compared to the averages found in positive samples from other parts of Brazil and are described in Table 1.

The indirect immunofluorescence test found 15 animals $(34.1 \%)$ with the antibody titers IgG anti-T.vivax varying from 80 to 320 (Fig. 1b); 29 of 44 animals $(65.9 \%)$ were negative. The nine animals that were found positive through blood smears were also found positive by indirect immunofluorescence. Six animals that were found negative through blood smears presented the antibodies IgG anti-T. vivax in the indirect immunofluorescence test, with antibody titers varying from 80 to 160 . These six animals were excluded from further analysis.

Hematological analysis demonstrated that in general no significant differences were observed in the erithrogram and leukogram in both groups of animals. A discreet lymphocytosis, as compared to the reference values [24] were observed in both groups of animals (Table 2).

Our data demonstrated that out of the 38 animals analyzed for clinical and reproductive parameters, $76.3 \%$ (29/38) were considered not infected and $23.7 \%$ (9/38) were classified as infected. The mucosa coloration, behavior, and palatability did not show any considerable variation in positive bulls when compared to negative bulls. However, rectal temperature was greater in infected animals when compared to non-infected animals,
$38.9 \pm 0.3{ }^{\circ} \mathrm{C}$ and $38.4 \pm 0.5{ }^{\circ} \mathrm{C} \quad(p<0.05)$, respectively (Fig. 2a). Libido evaluation found that infected bulls had higher score, ranging from 2.0 to $7.0(5.0 \pm 1.6)$, than the non-infected bulls, ranging from 3.0 to $10.0(7.5 \pm 2.1)$ (Fig. 2b). According to the table of libido classification, the Zebu bulls of this study revealed that infected bulls had libido values that were considered "questionable" to "good" whereas the non-infected animals had libido values that were considered "very good" and "excellent". Statistically, the libido of positive bulls was inferior $(p<0.05)$ to that of negative bulls. The results for ejaculate volume showed that infected bulls had higher collected volume when compared to non-infected animals, $8.2 \pm 2.7 \mathrm{~mL}$ and $6.4 \pm$ $1.8 \mathrm{~mL}(p<0.05)$, respectively (Fig. 2c).

The evaluation of sperm vigor did not show any difference between infected and non-infected animals with score averages ranging from of 2.6 to $3.2(2.9 \pm 0.3)$ and 2.0 to $4.0(3.0 \pm 0.4)$, respectively (Fig. $2 \mathrm{~d}$ ). Spermatic concentration of infected and non-infected animals also did not differ significantly between infected and noninfected animals, ranging from 0.5 to $1.2(0.9 \pm 0.2$ sperm counts $\left.\times 10^{6} / \mathrm{mL}\right)$ and 0.5 to $1.6(0.9 \pm 0.3$ sperm counts $\times 10^{6} / \mathrm{mL}$ ), respectively (Fig. 2e). Spermatic motility varied from 58.2 to $70.0 \%(64 \pm 3.8)$ for infected animals, and from 33.3 to $70.0 \%(65.3 \pm 8.5)$ for noninfected animals, which were not significantly different (Fig. 2f).

\section{Discussion}

There are many techniques for diagnosing infection with T. vivax such as blood smears, lymph node aspiration, and inoculation of mice, however, we found that the microhematocrit technique described by Woo [16] to be effective at discriminating infected animals. The biometric results for the parasites in this study were similar to that found in other T. vivax isolates from other Brazilian states [8] thus confirming the morphometric diagnosis of $T$. vivax in bulls from CSAI [18].

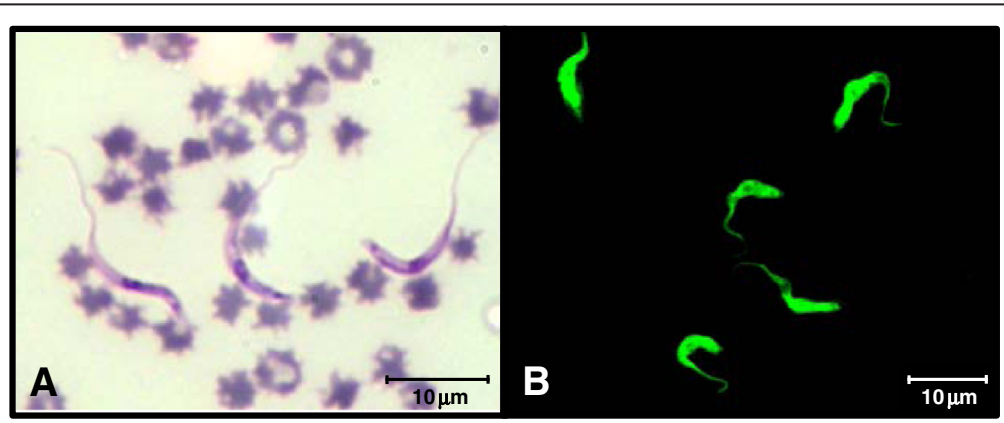

Fig. 1 a Trypomastigotes of T. vivax in a blood smear of an infected animal dyed with Quick Panoptic and seen using an optical microscope $1,000 \times$ magnification. $\mathbf{b}$ The form of trypomastigotes marked with fluorescein isothiocyanate from indirect immunofluorescence of a positive animal. Image obtained using confocal microscope (Zeiss ${ }^{\circledR}$ LSM 510 Meta) 1000x magnification 
Table 2 Hematological records in T. vivax-infected Zebu bulls

\begin{tabular}{|c|c|c|}
\hline Parameters & Non-infected & T. vivax-infected \\
\hline \multicolumn{3}{|l|}{ Red Blood Cells (RBC) } \\
\hline Erythrocytes $\left(\right.$ cells $\left./ \mathrm{mm}^{3}\right)\left(5-10 \times 10^{6}\right)$ & $8.2 \pm 1.1 \times 10^{6}$ & $7.8 \pm 1.1 \times 10^{6}$ \\
\hline Hemoglobin (g/dL) (8-15) & $11.7 \pm 1.9$ & $11.3 \pm 1.9$ \\
\hline Hematocrit (\%) (24-46) & $34.5 \pm 6.4$ & $34.0 \pm 6.5$ \\
\hline MCV (fL) (40-60) & $42.6 \pm 8.6$ & $35.7 \pm 17.7$ \\
\hline MCHC (g/dL) (30-36) & $33.3 \pm 2.0$ & $33.4 \pm 1.3$ \\
\hline \multicolumn{3}{|l|}{ White Blood Cells (WBC) } \\
\hline Total leukocytes (cells $\left./ \mathrm{mm}^{3}\right)\left(4-12 \times 10^{3}\right)$ & $11.6 \pm 2.4 \times 10^{3}$ & $11.8 \pm 4.1 \times 10^{3}$ \\
\hline Eosinophils (cells $\left./ \mathrm{mm}^{3}\right)\left(0-2.4 \times 10^{3}\right)$ & $0.27 \pm 0.16 \times 10^{3}$ & $0.45 \pm 0.15 \times 10^{3}$ \\
\hline Neutrophils (cells/mm $\left./ \mathrm{mm}^{3}\right)\left(0.6-4 \times 10^{3}\right)$ & $2.2 \pm 1.0 \times 10^{3}$ & $2.2 \pm 1.4 \times 10^{3}$ \\
\hline Monocytes (cells/mm³) $\left(0.03-0.84 \times 10^{3}\right)$ & $0.24 \pm 0.18 \times 10^{3}$ & $0.27 \pm 0.19 \times 10^{3}$ \\
\hline Lymphocytes (cells $\left./ \mathrm{mm}^{3}\right)\left(2.5-7.5 \times 10^{3}\right)$ & $8.5 \pm 1.7 \times 10^{3 a}$ & $9.1 \pm 3.9 \times 10^{3 a}$ \\
\hline
\end{tabular}

Data presented as mean \pm standard deviation; Reference Values [24] are provided below each parameter; ${ }^{a}$ indicate values outside the reference values

(A) Rectal temperature

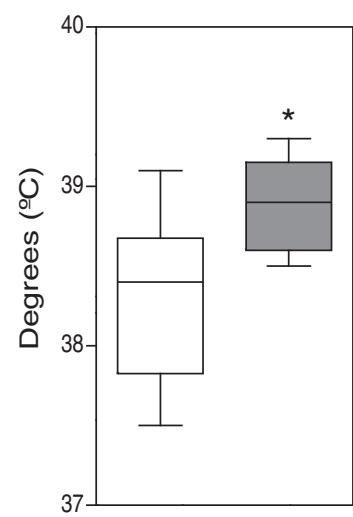

(D) Vigor

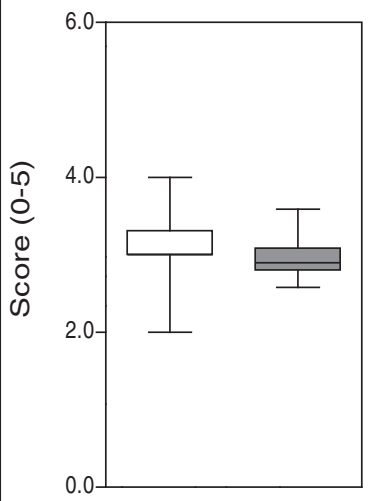

(B) Libido

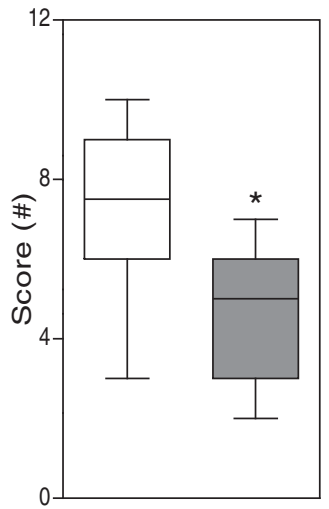

(E) Concentration

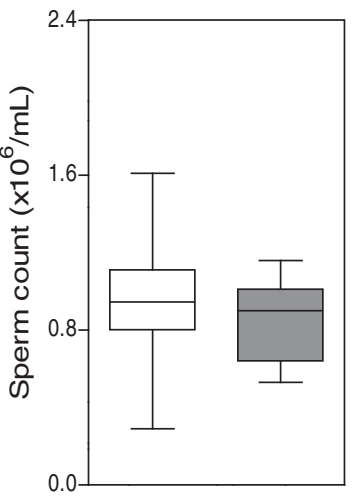

(C) Ejaculated volume

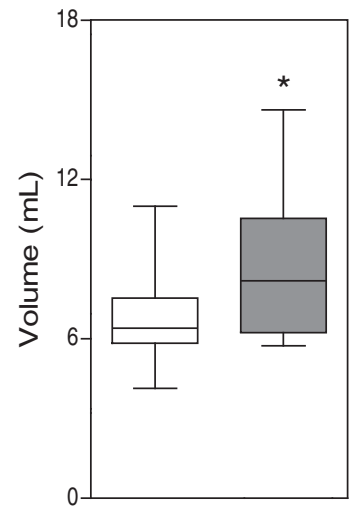

(F) Motility

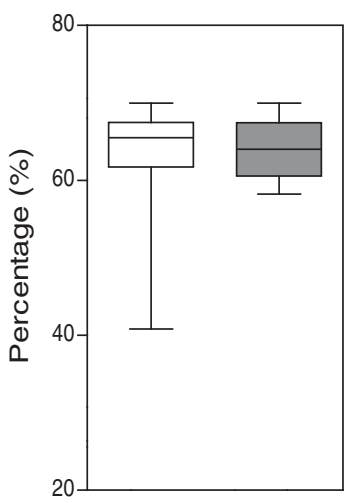

Fig. 2 Mean Values of rectal temperature (a), libido (b), ejaculate volume (c), spermatic vigor (d), spermatic concentration (e) and spermatic motility $(\mathbf{f})$ in ejaculates of bulls non-infected (white rectangle symbol) and naturally infected with $T$. vivax (grey rectangle symbol). *Significant differences at $p<0.05$ between non-infected and infected groups. \# According to table of libido classification for Zebu bulls of the Brazilian College of Animal Reproduction [23]: 0 to $3=$ questionable; 4 to $6=$ good; 7 to $8=$ very good; 9 to $10=$ excellent or superior 
The seroprevalence of $34.1 \%$ for the sample of bulls from CSAI was significant. However, the prevalence at CSAI was lower than what was found by Madruga et al. [25], who verified a prevalence of $37.7 \%$ in cities from the state of Pará and $56.0 \%$ in the state of Mato Grosso do Sul, and Cuglovici et al. [20], who found a prevalence of $35.7 \%$ in the region of Igarapé, state of Minas Gerais.

The infected animals in this study did not show clinical symptoms of trypanosomiasis, which can be explained by the good physical and nutritional status of the animals. A similar observation was made by Schenk et al. [26], who indicated that good nutritional status establishes equilibrium between parasite and host (trypanotolerance), and therefore the animal is clinically normal. In addition, Batista et al. [4] and Osório et al. [27] reported a natural resistance to the infection in bovines from Latin America.

In this study, we did not find any hematological alterations associated with the T. vivax infection. A discreet lymphocytosis, as compared to the reference values was observed in both groups of animals which may be a consequence of animal management [28] at the Central Station of Artificial Insemination (CSAI).

According to studies developed by Almeida et al. [29], Batista et al. [30] and Schenk et al. [26], animals with the highest level of parasitemia experience an increase in body temperature, however, the significant increase in rectal temperature of positive animals in the present study was within the interval considered as "normal" as described by DuPreez [31], which can, again, be justified by good nutrition according to observations of Van Den Bossche \& Rowlands in 2001 [3].

The results of the present study showed that $T$. vivax produces a negative effect in the libido of infected animals. According to Schenk et al. [26], this parasitism can cause a decrease in the libido especially during febrile periods and in condition of hypoxia. The average rectal temperature in positive bulls from the CSAI was higher than that observed in non-infected bulls. We hypothesized the febrile state triggered by the T. vivax infection would contribute to an impaired general clinical status of Zebu bulls and subsequently compromised their reproductive performance. This hypothesis was constructed based on previous findings reported by Schenk et al. [26], Setchell [32] and Bezerra \& Batista [11]. The latter have demonstrated that T. vivax infection can lead to reproductive pathologies in male leading to decreased semen quality. In chronic cases of disease, infertility or even sterility might be present [11]. According to Setchell [32] hyperthermia, anorexia and anemia caused by $T$. vivax contribute to the triggering of the degeneration of reproductive organs. The conditions observed in the infected animals in our study, could have led to testicular degeneration and, consequently, compromised the performance of animals in semen production. Ultimately, it is possible that these conditions of infection could have negative impact on the reproductive capacity of the animals. Bezerra \& Batista [11] described that bovines with increased body temperature for a long period of time experienced a reduction in plasmatic concentration of testosterone. This fact could be a consequence of many protozoan produced events in the testicles that would explain the reduction of libido in the positive animals.

According to Galloway [33], ejaculated volume can vary between 2 to $6 \mathrm{~mL}$ due to the method of sample collection when using an artificial vagina in Zebu. However, variation sometimes also depends on the animal itself such as deficiency in the contraction of deferent vessels and the epididymis tail in response to stimulus. Sekoni et al. [14] and Adamu et al. [13] have reported that T. vivax-infected presented reduced ejaculated volume. Adamu et al. [13] reported damage to the accessory gland of males associated with the toxins released locally by the parasite, such as hemolysins, inflammatory and permeability factors, factors activating the complement system, immunosuppression factors, and substances liberated by dead trypanosomes. In this study, we have found that the average ejaculated volume was higher in T. vivax positive bulls and associated with a reduction of spermatic concentration. These findings may be related to T. vivax-related pathological conditions previously reported by Bezerra e Batista [11] such as interstitial perivascular epididimitis or with hyperplasia of epididimal epithelium cause by the parasite as reported by Adamu et al. [13]. These pathological conditions are associated with increased body temperature [32], as observed in the T. vivax-infected bulls included in our investigation.

\section{Conclusion}

Our results demonstrated that the T. vivax infection in Zebu bulls from CSAI caused patent parasitemia, induced a febrile state, promoted reduction in the libido and increased the ejaculate volume. These conditions together may account to decrease the performance of these animals.

\section{Abbreviations}

CEEA: Ethics in Animal Experimentation Committee; CSAl: Central Station of Artificial Insemination; EDTA: Ethylenediamine tetraacetic acid; F: Length of free flagellum; FITC: Fluorescein isothiocyanate; g: Gravity (centrifugal force); IFI: Indirect Immunoflorescence; IgG: Immunoglobulin G; Kl: Kinetoplast index; KN: Kinetoplast distance from kinetoplast to the middle of the nucleus; L: Total length of parasite including free flagellum; MCHC: Mean Corpuscular Hemoglobin Concentration; MCV: Mean Corpuscular Volume; NA: Distance from the middle of the nucleus to the end of anterior extremity; NI: Nuclear index; PBS: Phosphate buffered saline; PK: Distance from the end of posterior extremity to kinetoplast; PN: Distance from the end of posterior extremity to the middle of the nucleus; RBC: Red Blood Cell; WBC: White Blood Cell. 


\section{Competing interests}

The authors confirm that they have no conflicts of interest in this work.

\section{Authors' contributions}

JFFB, MSSA, OAMF participated in the design of the study, the statistical analysis, and drafting or revising the manuscript. PBB, DMM, GCG, ABV, MFCS, $\mathrm{CPB}$ participated in obtaining the samples and conducting the experiments, and performing the immunoassays and parasitological test. ERB participated in the design of the study, in coordination of research, and in drafting the manuscript. All authors read and approved the final manuscript.

\section{Acknowledgments}

This work was financially supported by CNPq (Conselho Nacional de Desenvolvimento Científico e Tecnológico, Brazil), FAPEMIG (Fundação de Amparo a Pesquisa do Estado de Minas Gerais, Brazil) and PAPE-UNIUBE (Programa de Apoio a Pesquisa da Universidade de Uberaba, Minas Gerais, Brazil). OAMF is thankful to CNPq for the PQ fellowship program. The authors thank the Program for Technological Development in Tools for Health PDTIS - FIOCRUZ for use of its facilities.

Received: 31 October 2014 Accepted: 2 October 2015

Published online: 14 October 2015

\section{References}

1. Gardiner PR. Recent studies of the biology of Trypanosoma vivax. Adv Parasit. 1989;28:229-313.

2. Silva RAMS, Seidl A, Ramirez L, Dávila AMR. Trypanosoma evansi e Trypanosoma vivax - Biologia, Diagnóstico e Controle. Corumbá: EMBRAPA; 2002. p. 141.

3. Van Den Bossche P, Rowlands GJ. The relationship between the parasitological prevalence of trypanosomal infections in cattle and herd average packed cell volume. Acta Trop. 2001;78:163-70.

4. Batista JS, Riet-Correa F, Teixeira MMG, Madruga CR, Simões SDV, Maia TF. Trypanosomiasis by Trypanosoma vivax in cattle in the Brazilian semiarid: Description of an outbreak and lesions in the nervous system. Vet Parasitol. 2007;143:174-81.

5. Linhares GFC, Filho FCD, Fernandes PR, Duarte SC. Tripanossomíase em bovinos no município de Formoso do Araguaia, Tocantins: relato de caso. Ciênc Anim Bras. 2006;7(4):455-60.

6. Batista JS, Bezerra FSB, Lira RA, Carvalho JRG, Rosado Neto AM, Petri AA, et al. Aspectos clínicos, epidemiológicos e patológicos da infecção natural em bovinos por Trypanosoma vivax na Paraíba. Pesq Vet Bras. 2008;28(1):63-9.

7. Guerra RMS, Feitosa-Junior AB, Santos HP, Silva ALA, Santos CG. Biometry of Trypanosoma vivax found in a calf in the state of Maranhão, Brazil. Cienc Rural. 2008:38:833-5.

8. Carvalho AU, Abrão DC, Facury-Filho EJ, Paes PRO, Ribeiro MFB. Ocorrência de Trypanosoma vivax no estado de Minas Gerais. Arq Bras Med Vet Zootec. 2008;60(3):769-71.

9. Silva RAMS, Silva JA, Schneider RC, Freitas J, Mesquita D, Mesquita T, et al. Outbreak of Trypanosomiasis due to Trypanosoma vivax (Ziemann, 1905) in bovines of the Pantanal, Brazil. Mem Inst Oswaldo Cruz. 1996;52:561-2.

10. Batista JS, Oliveira AF, Rodrigues CMF, Damasceno CAR, Oliveira IRS, Alves HM, et al. Infection by Trypanosoma vivax in goats and sheep in the Brazilian semiarid region: from acute disease outbreak to chronic cryptic infection. Vet Parasitol. 2009;165:131-5.

11. Bezerra FSB, Batista JS. Efeitos da infecção por Trypanosoma vivax sobre a reprodução: uma revisão. Acta Veterinaria Brasilica. 2008;2(3):61-6.

12. Almeida $\mathrm{KS}$, Freitas FLC, Jorge RLN, Nogueira CAS, Machado RZ, Nascimento AA. Aspectos hematológicos da infecção experimental por Trypanosoma vivax em ovinos. Ciênc Anim Bras. 2008;9(4):1121-7.

13. Adamu S, Fatihu MY, Useh NM, Mamman M, Sekoni VO, Esievo KAN. Sequential testicular and epididymal damage in zebu bulls experimentally infected with Trypanosoma vivax. Vet Parasit. 2007;143:29-34.

14. Sekoni VO, Rekwot PI, Bawa EK. Effects of Trypanosoma vivax and Trypanosoma congolense infections on the reaction time and semen characteristics of Zebu (Bunaji) x Friesian crossbred bulls. Theriogenology. 2004;61(1):55-62

15. Camargo ME. Fluorescent antibody test for the serodiagnosis of Chagas' disease. Technical modification employing preserved cultural forms of Trypanosoma cruzi in a slide test. Rev Inst Med trop S Paulo. 1966;8:229-34.

16. Woo PTK. The haematocrit centrifuge technique for the diagnosis of african trypanosomiasis. Acta Trop. 1970;27(4):384.
17. Brener Z. Therapeutic activity and criterion of cure on mice experimentally infected with Trypanosoma cruzi. Rev Inst Med Trop. 1962;4:389-96.

18. Hoare CA. The trypanosomes of mammals. Oxford: Blackwell Scientific Publications; 1972. p. 60-80.

19. Shaw JJ, Lainson R. Trypanosoma vivax in Brazil. Ann Trop Med Parasitol. 1972;66:25-32.

20. Paiva F, Lemos RAA, Oshiro ET, Salvador SC, Nakazato L. Ocorrência de Trypanosoma vivax em bovinos no Estado de Mato Grosso do Sul. Rev Bras Parasitol Vet. 1997;6(2):349.

21. Cuglovici DA, Bartholomeu DC, Reis-Cunha JL, Carvalho AU, Ribeiro MF. Epidemiologic aspects of an outbreak of Trypanosoma vivax in a dairy cattle herd in Minas Gerais state. Brazil Vet Parasitol. 2010;169:320-6.

22. Fonseca VO, Chow LA. Características seminais de touros zebus com degeneração testicular transitória. Arq Bras Med Vet Zootec. 1995;47:16.

23. CBRA- Colégio Brasileiro De Reprodução Animal. Manual para exame andrológico e avaliação de sêmen animal. 3rd ed. Belo Horizonte: CBRA; 2013. p. 87.

24. Radostitis OM, Gay CC, Blood DC, Hinchcliff KW. Clínica veterinária: um tratado de doenças dos bovinos, ovinos, suínos, caprinos e equinos. 9th ed. Rio de Janeiro: Guanabara Koogan; 2002. p. 1737.

25. Madruga CR, Araújo FR, Cavalcante-Goes G, Martins C, Pfeifer IB, Ribeiro LR, et al. The development of an enzymelinked immunosorbent assay for Trypanosoma vivax antibodies and its use in epidemiological surveys. Mem Inst Oswaldo Cruz. 2006;101:801-7.

26. Schenk MAM, Mendonça CL, Madruga CR, Kohayagawa A, Araújo FR. Avaliação clínico-laboratorial de bovinos nelore infectados experimentalmente com Trypanossoma vivax. Pesq Vet Bras. 2001;21(4):157-61.

27. Osório ALAR, Madruga CR, Desquesnes M, Soares CO, Ribeiro LRR, Costa SCG. Trypanosoma (Duttonella) vivax: its biology, epidemiology, pathogenesis, and introduction in the new world - A review. Mem Inst Oswaldo Cruz. 2008;103:1-13.

28. Latimer KS, Mahaffey EA, Prasse KW. Duncan \& Prasse's Veterinary Laboratory Medicine. Clinical Pathology. 4th ed. Ames, IA: lowa State Press; 2003.

29. Almeida KS, Freitas FLC, Tebaldi JH, Alessi AC, Machado RZ, Nascimento AA. Alterações clínicas, histopatológicas e enzimáticas em ovinos infectados experimentalmente por Trypanosoma vivax. Ciên Anim Bras. 2010;11(3):669-76.

30. Batista JS, Riet-Correa F, Barbosa RC, Guerra JL. Infecção experimental por Trypanosoma vivax em ovinos. Pesq Vet Bras. 2006;26:31-7.

31. DuPreez JH. Parameters for the determination and evaluation of heat stress in dairy cattle in South Africa. Onderstepoort J Vet Res. 2000;67:263-71.

32. Setchell BP. The parkes lecture heat and the testis. J Reprod Fertility. 1998;114:174-94

33. Galloway, DB. Fatores que afetam a fertilidade bovina. Belo Horizonte: Colégio Brasileiro de Reprodução Animal. 1979, p256.

\section{Submit your next manuscript to BioMed Central and take full advantage of:}

- Convenient online submission

- Thorough peer review

- No space constraints or color figure charges

- Immediate publication on acceptance

- Inclusion in PubMed, CAS, Scopus and Google Scholar

- Research which is freely available for redistribution 